Article

\title{
Modulation of Doxorubicin Intracellular Accumulation and Anticancer Activity by Triterpene Glycoside Cucumarioside $\mathrm{A}_{2}-2$
}

\author{
Ekaterina Menchinskaya $^{1, *}$, Tatiana Gorpenchenko ${ }^{2}\left(\mathbb{D}\right.$, Alexandra Silchenko $^{1}$, Sergey Avilov ${ }^{1}$ \\ and Dmitry Aminin 1,3 \\ 1 G.B. Elyakov Pacific Institute of Bioorganic Chemistry, Far-Eastern Branch of the Russian Academy of \\ Science, Prospect 100-letya Vladivostoka, 159, 690022 Vladivostok, Russia; sialexandra@mail.ru (A.S.); \\ avilov-1957@mail.ru (S.A.); daminin@piboc.dvo.ru (D.A.) \\ 2 Federal Scientific Center of the East Asia Terrestrial Biodiversity, Far-Eastern Branch of the Russian Academy \\ of Science, Prospect 100-letya Vladivostoka, 159, 690022 Vladivostok, Russia; gorpenchenko@biosoil.ru \\ 3 Department of Biomedical Science and Environmental Biology, Kaohsiung Medical University, 100, \\ Shih-Chuan 1st Road, Kaohsiung 80708, Taiwan \\ * Correspondence: ekaterinamenchinskaya@gmail.com; Tel.: +7(4232)31-99-32; Fax: +7(4232)31-40-50
}

Received: 27 August 2019; Accepted: 21 October 2019; Published: 23 October 2019

\begin{abstract}
The effect of treatment of Ehrlich ascites carcinoma (EAC) cells with multidrug resistance by holothurian triterpene glycoside, cucumarioside $\mathrm{A}_{2}-2\left(\mathrm{CA}_{2}-2\right)$ was evaluated. Calcein-AM efflux assay and doxorubicin (DOX) uptake and retention measurement in cancer cells, as well as determination of DOX cytotoxic and anticancer effects were applied. Treatment of EAC cells with $\mathrm{CA}_{2}-2(0.01-0.1 \mu \mathrm{M})$ blocked Calcein-AM and DOX efflux from cancer cells and increased the accumulation and cytotoxicity of DOX in EAC cells. Moreover, pre-treatment of mice with EAC by $\mathrm{CA}_{2}-2(10 \mu \mathrm{g} / \mathrm{kg} / 5$ days, intraperitoneal injection (i.p.)), then transplantation of tumor cells into fresh animals and subsequent treatment of these mice with DOX $(2 \mathrm{mg} / \mathrm{kg} / 3$ days i.p.) significantly increased average life span (ALS) of mice bearing a tumor and therefore boosted the antitumor effect of doxorubicin in vivo.
\end{abstract}

Keywords: cucumarioside $\mathrm{A}_{2}$-2; doxorubicin; ehrlich ascites carcinoma; MDR; sea cucumbers; triterpene glycosides

\section{Introduction}

The resistance of tumor cells to many toxic antitumor drugs, which are used for chemotherapy of cancer and are dissimilar in chemical structure and mechanism of action, has long been a known phenomenon called multidrug resistance (MDR). Cells that have MDR or acquire it during chemotherapy become resistant to the action of drugs and the destruction or inhibition of their proliferation requires the use of chemotherapeutic cytostatics such as cyclophosphamide, doxorubicin, vinblastine, cisplatin and fluorouracil in doses so large that they often cause unwanted toxic effects. The most common MDR mechanism is the activation of transmembrane transport proteins that remove various substances from the cell. The main protein of this type is P-glycoprotein (P-gp) [1]. P-gp acts as a pump which, using the energy of ATP, can pump a wide variety of substances from the cell including a variety of antitumor cytostatics and cytotoxins that freely penetrate through the cell membranes by diffusion. The use of new effective MDR blockers would help solve the problem arising from the use of chemotherapy.

It is known that there are drugs that help to overcome MDR of tumors, such as verapamil, cyclosporin A, nifedipine and its derivatives, amiodarone, trifluoperazine, quinine and others [2]. The disadvantage of these compounds is the presence of serious side effects in the doses necessary 
to enhance the action of antitumor drugs. In particular, verapamil, an effective inhibitor of P-gp, causes heart failure and brain damage, and cyclosporin A has immunosuppressive activity. In this regard, the search for MDR inhibitors among natural compounds with less pronounced side effects seems relevant.

Natural compounds of marine origin including triterpene glycosides from holothurians attract attention as substances possessing various types of biological activity. It was previously established that a number of triterpene glycosides from sea cucumbers of the genus Cucumaria, cucumarioside $\mathrm{A}_{2}-2$ and frondoside $\mathrm{A}$ in particular exhibit a pronounced antitumor effect in vitro and in vivo; block cell proliferation, DNA biosynthesis and the cell cycle, induce apoptosis and inhibit colony formation of tumor cells [3-6]. Using the standard Calcein-AM efflux assay only, it has recently been demonstrated that the same triterpene glycosides are able to increase the accumulation of fluorescent probe in tumor cells probably due to MDR inhibition [7,8]. However, the effect of glycosides on magnification of sensitivity of cancer cells to antitumor compounds by MDR blocking has not been shown. In this regard, the aim of our work was to study the effect of triterpene glycoside, cucumarioside $A_{2}-2$, on the blocking of multidrug resistance of mouse Ehrlich ascites carcinoma cells in more detail, including glycoside effects upon cytostatic drug, doxorubicin, accumulation, efflux and cytotoxicity against cancer cells in vitro, as well as the combined antitumor effect of glycoside and doxorubicin using mice bearing Ehrlich carcinoma in vivo.

\section{Results}

\subsection{Cucumarioside $A_{2}-2$ Increases the Amount of Calcein AM and Doxorubicin in Tumor EAC Cells}

We found that the studied triterpene glycoside $\mathrm{CA}_{2}-2$ effectively blocks the activity of P-gp at a concentration of $0.1 \mu \mathrm{M}$ resulting in an increase in the quantity of Calcein probe in the cytoplasm. Blocking MDR in EAC cells and an increase in the fluorescence intensity of the Calcein probe accumulated in the cytoplasm amounted to about $50 \%$ as compared to control level similarly to standard MDR inhibitor, verapamil (Figure 1B).

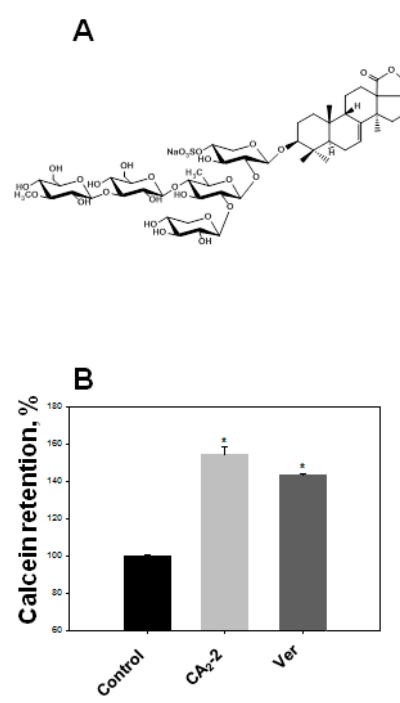

C
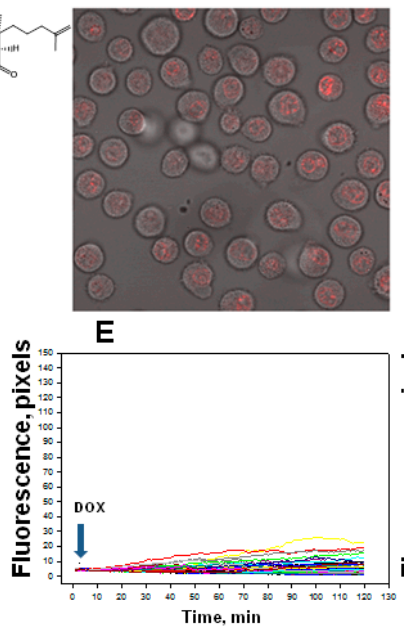

D
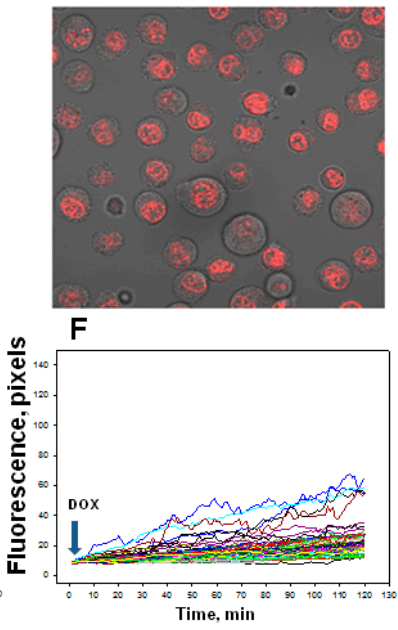

Figure 1. Effect of cucumarioside $\mathrm{A}_{2}-2\left(\mathrm{CA}_{2}-2\right)$ on the accumulation of a Calcein-AM and doxorubicin (DOX) in Ehrlich ascites carcinoma (EAC) cells. Chemical structure of $\mathrm{CA}_{2}-2$ (A). Effect of $\mathrm{CA}_{2}-2$ $(0.1 \mu \mathrm{M})$ and verapamil (Ver, $0.001 \mu \mathrm{g} / \mathrm{mL}$ ) on the accumulation of a Calcein-AM (B). Accumulation of DOX in the cell nuclei. Images obtained $2 \mathrm{~h}$ after incubation with DOX: Control cells (C) and cells pre-exposed with $\mathrm{CA}_{2}-2(\mathrm{D})$. The effect of $\mathrm{CA}_{2}-2(0.01 \mu \mathrm{M})$ on the dynamics of DOX accumulation in the nuclei of EAC cells: Control cells (E) and cells pre-exposed with $\mathrm{CA}_{2}-2$ (F). Records of changes in the fluorescence of the nuclei of individual cells in a monolayer are shown. Arrows indicate the time of DOX administration. ${ }^{*} p<0.05$. 
Using confocal microscopy, we found that the incubation of EAC cells with $\mathrm{CA}_{2}-2$ in the concentration range of $0.001-0.1 \mu \mathrm{M}$ for $2 \mathrm{~h}$ leads to a noticeable increase in the dynamics of doxorubicin uptake and its accumulation in the nuclei of tumor cells. Figure 1C-F clearly shows that after $2 \mathrm{~h}$ from the beginning of the experiment, the final concentration of doxorubicin accumulated in the nuclei is significantly higher in the cells treated with $\mathrm{CA}_{2}-2$ compared with the control untreated cells. An inversely proportional dependence of the MDR-inhibiting effect on glycoside concentration was noted. It was shown that preliminary incubation of the cells with $\mathrm{CA}_{2}-2$ at a concentration of $0.001 \mu \mathrm{M}$ led to maximum accumulation of doxorubicin in the nuclei of EAC cells (Figure 2A).

A

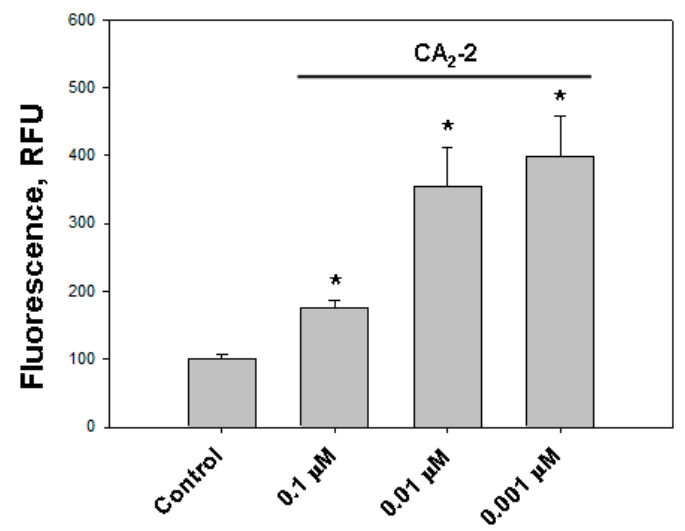

B

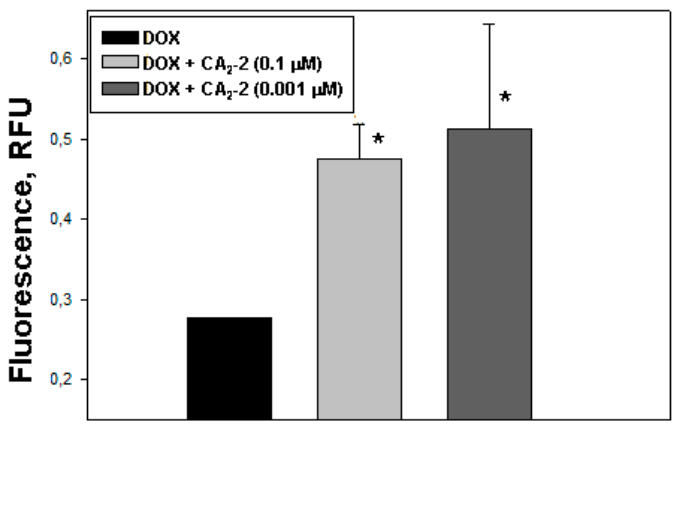

Figure 2. The effect of $\mathrm{CA}_{2}-2$ on the accumulation and efflux of DOX in EAC cells. The content of DOX in the cell nuclei after its accumulation within $2 \mathrm{~h}(\mathbf{A})$ and its residual amount in the nuclei 1 hour after washing the cells (B) are shown. ${ }^{*} p<0.05$.

The study of DOX release from tumor cells was performed using spectrofluorimetry. We found that the nanomolar concentrations of $\mathrm{CA}_{2}-2$ are able to delay the efflux of DOX from the cytoplasm of tumor cells after its initial accumulation in the nuclei. A noticeable effect of inhibition was observed at a concentration of glycoside of 0.001 and $0.1 \mu \mathrm{M}$ after preliminary incubation of cancer cells with glycoside and subsequent accumulation of DOX in EAC cells for $2 \mathrm{~h}$. The greatest effect of delaying the release of fluorescent antitumor antibiotic was observed $1 \mathrm{~h}$ after washing the cells at a concentration of glycoside of $0.001 \mu \mathrm{M}$ (Figure 2B).

\subsection{Cucumarioside $A_{2}-2$ Enhances the Cytotoxic Activity of Doxorubicin in Vitro}

The studying of the influence of $\mathrm{CA}_{2}-2$ on DOX cytotoxic activity showed that glycoside at a concentration of 0.1 and $0.01 \mu \mathrm{M}$ significantly increases DOX cytoxicity (Figure 3A,B). The greatest effect was found at a concentration of $0.1 \mu \mathrm{M}$, which decreases cell viability to more than $80 \%$, compared with DOX alone. The glycoside concentration of $0.01 \mu \mathrm{M}$ was shown to inhibit cell viability up to around $25 \%$, and the minimal test concentration of $0.001 \mu \mathrm{M}$ did not affect the cytotoxic activity of DOX. At the same time, $\mathrm{CA}_{2}-2$ at a concentration of $0.1 \mu \mathrm{M}$, as well as doxorubicin at a concentration of $25 \mu \mathrm{M}$ did not exhibit cytotoxic activity by itself (Figure 3B). 
A

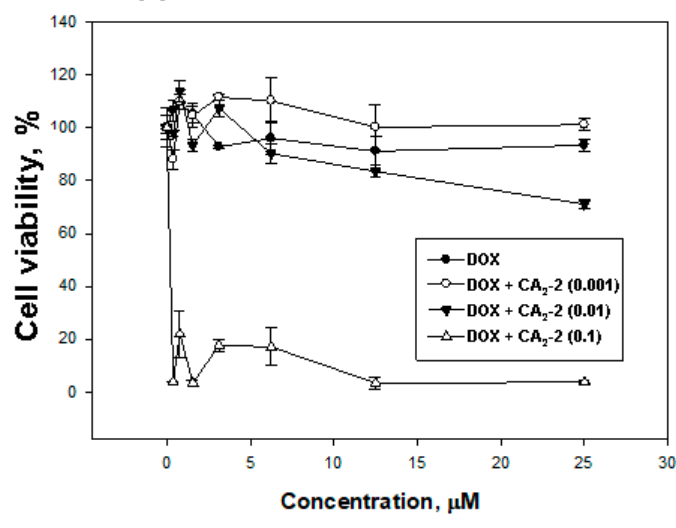

B

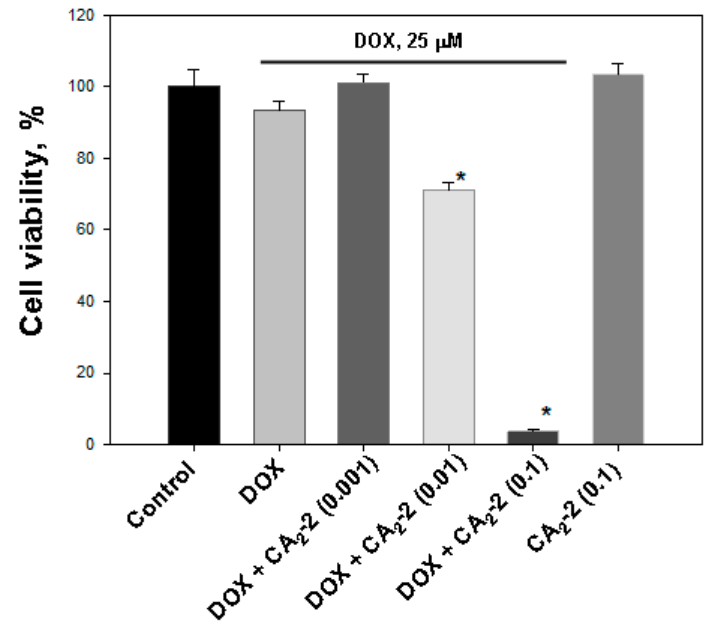

Figure 3. The effect of $\mathrm{CA}_{2}-2$ on the cytotoxic activity of DOX (A) against EAC cells, evaluated by MTT. Cytotoxic activity of DOX $(25 \mu \mathrm{M})$ and various concentrations of $\mathrm{CA}_{2}-2(\mathbf{B})$. Cells were pre-exposed with $\mathrm{CA}_{2}-2$ for $2 \mathrm{~h}$ and than incubated with DOX for the next $48 \mathrm{~h}$. ${ }^{*} p<0.05$.

\subsection{Cucumarioside $A_{2}-2$ Increases the Survival of Mice with Ehrlich Ascites Carcinoma Treated with Doxorubicin}

It was found that the survival time of control animals implanted with untreated cancer cells was less than that of animals inoculated with the cells obtained from $\mathrm{CA}_{2}-2$ treated animals. In the first control group, group 1, an average life span (ALS) of 21.5 days was observed. In the second group of control animals subjected to in vivo exposure to $\mathrm{CA}_{2}-2$, which then received only physiological saline, an increase in the ALS was indicated. Thus, in group 2 the last animal died on the 36th day while in the control group 1, on the 23rd day of the experiment. So, ALS of mice in group 2 was 29.8 days (Table 1 , Figure 4).

Table 1. The effect of cucumarioside $\mathrm{A}_{2}-2$ and doxorubicin on the survivability of mice with Ehrlich ascites carcinoma (inoculation of $2.0 \times 10^{6}$ cells per animal).

\begin{tabular}{cccc}
\hline Group of Animals & CA $_{\mathbf{2}}-\mathbf{2}$, dose & DOX, dose & ALS, days \\
\hline 1, Control & - & - & $21.5 \pm 0.4$ \\
\hline 2, Control $+\mathrm{CA}_{2}-2$ & $10 \mu \mathrm{g} / \mathrm{kg} / 5$ days $i . p$. & - & $29.8 \pm 3.2$ \\
\hline $3, \mathrm{DOX}$ & - & $2 \mathrm{mg} / \mathrm{kg} / 3$ days i.p. & $60.8 \pm 5.9$ \\
\hline $4, \mathrm{DOX}+\mathrm{CA}_{2}-2$ & $10 \mu \mathrm{g} / \mathrm{kg} / 5$ days i.p. & $2 \mathrm{mg} / \mathrm{kg} / 3$ days i.p. & $70.0 \pm 0.0$ \\
\hline
\end{tabular}

When using DOX at a dose of $2 \mathrm{mg} / \mathrm{kg}$, a significant increase in life expectancy was observed (group 3). The first mouse in this group died only on the 42nd day after tumor inoculation, the second mouse fell on the 52nd day, and the other animals in the group remained alive until the 70th day of observation. ALS in this group was 60.8 days, and animal survivability by day 70 was $60 \%$. In group 4 the animals received tumor cells from mice previously exposed to $\mathrm{CA}_{2}-2$ in vivo and then subsequently were treated with DOX, the survival rate was $100 \%$ for the entire observation period of 70 days (Table 1 , Figure 4). 


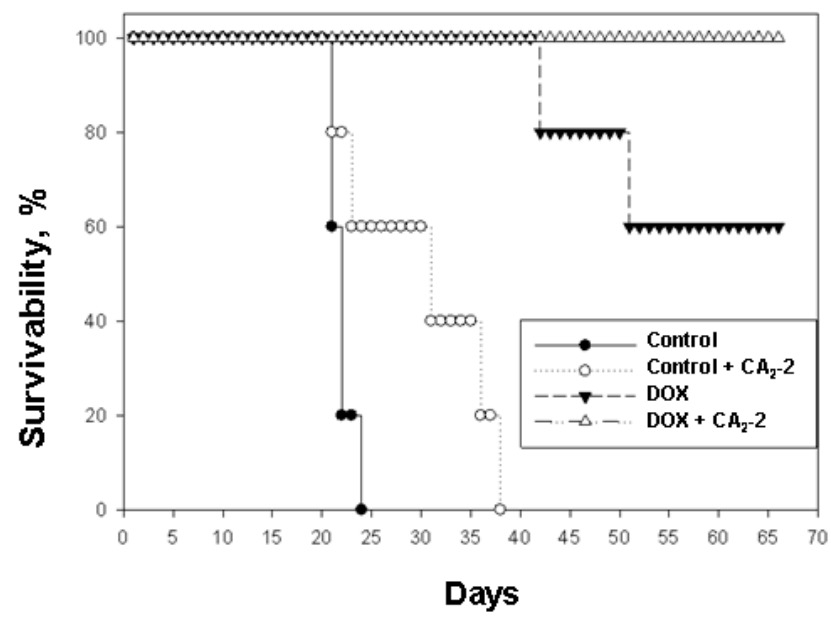

Figure 4. The effect of cucumarioside $\mathrm{A}_{2}-2$ on the antitumor activity of doxorubicin in the in vivo model of mouse Ehrlich ascites carcinoma.

\section{Discussion}

Doxorubicin is a well-known medicinal drug used for therapy of various types of tumors. It is an antitumor antibiotic of the anthracycline series. It has an antimitotic and antiproliferative effect. The mechanism of the antitumor effect of DOX is the interaction with DNA, the formation of free radicals and the suppression of nucleic acid synthesis. One of the noted drawbacks of using doxorubicin is the emergence in tumor cells resistant to this cytostatic as a result of activation of the multidrug resistance mechanism. At the same time, it was shown that a number of compounds (for example, calcium channel blockers verapamil and diltiazem) can enhance the antitumor effect of doxorubicin by suppressing MDR of tumor cells [9].

It is known that Ehrlich ascites carcinoma cells exhibit multidrug resistance phenomenon due to overexpression of P-glycoprotein in response to the action of a number of antitumor compounds [10,11]. We have found that incubation of Ehrlich ascites carcinoma cells with the holothurian triterpene glycoside, cucumarioside $\mathrm{A}_{2}-2$, leads to increasing doxorubicin accumulation, blocking the release of doxorubicin and increase in its retention in mouse tumor cells. Despite the fact that the rate of DOX uptake in tumor cells pre-exposed with different concentrations of $\mathrm{CA}_{2}-2$ was different, the final amount of doxorubicin remaining in the cells was approximately the same. This leads to a significant increase in the cytotoxic activity of doxorubicin against tumor cells in vitro. This effect can be directly related to the ability of $\mathrm{CA}_{2}-2$ to block MDR, since $\mathrm{CA}_{2}-2$ alone did not exhibit a cytotoxic effect. This fact can be confirmed by the results of the assessment of blocking of Calcein-AM release from tumor cells, which are the standard experimental approach to search for MDR blockers [12].

In addition, we have shown that in vivo pre-treatment of mice with Ehrlich ascites carcinoma by $\mathrm{CA}_{2}-2$ followed by transplantation of such treated tumor cells into intact animals and subsequent treatment of these mice with doxorubicin significantly increases the antitumor activity of doxorubicin in vivo. This effect can be also attributed to the blocking of MDR in EAC cells, which results in the increasing of tumor cell sensitivity to cytostatics owing to their increased accumulation in cells.

Among triterpenoids of marine origin, substances were found that possess various types of biological activity, including the selective cytotoxic activity against MDR cells, as well as the blocking of P-gp. Thus, sipholenol A isolated from the Red Sea sponge Callyspongia (Siphonochalina) siphonella significantly eliminated the resistance of P-gp overexpressing KB-C2 cells to colchicine. Sipholenol A did not act on KB-3-1 epidermoid drug-sensitive carcinoma cells (which do not express P-gp) and on MRP1-expressing KB-CV60 cells, so the researchers suggested that this triterpenoid is selective for P-gp and consider the sipholenol A as a potential P-pg modulator [13].

Later, three new sipholan triterpenoids were isolated from the same sponge, sipholenone E, sipholenol L and siphonellinol D, and studied as potential inhibitors of P-glycoprotein. 
These compounds enhanced the cytotoxic activity of several well-known anticancer drugs including colchicine, vinblastine and paclitaxel, which are substrates for P-gp, significantly increasing the sensitivity of cancer cells with a P-gp overexpressed phenotype (KB-C2) in a dose-dependent manner. At the same time, these sipholan triterpenoids did not affect the sensitivity of KB-3-1 and KB-C2 cells to cisplatin, a chemotherapeutic drug that is not a substrate for P-gp [14].

Recently, during the screening assay it was found that the holothurian triterpene glycosides, cucumarioside $\mathrm{A}_{2}-2$ from Cucumaria japonica and frondoside A from C. frondosa, as well as their complexes with cholesterol, are able to effectively block MDR and prevent the release of low molecular weight fluorescent agent Calcein-AM from tumor cells [7,8]. Besides, the new medicinal preparation, Cumaside created on the basis of the triterpene glycoside, cucumarioside $A_{2}-2$, led to a synergistic effect and enhanced the antitumor effect of the cytostatic drug 5-fluorouracil in combined antitumor therapy, which can also be a manifestation of MDR blocking [15].

It is well known that the membranotropic properties of holothurians triterpene glycosides such as hemolytic, cytotoxic or immunostimulatory activity largely depends on the presence of carbohydrate chain in the molecule and especially the presence of a number of sulphate groups in carbohydrate moieties. Usually, aglycone alone is completely inactive [16,17]. In the very near future, we plan to investigate the ability of triterpene glycosides with different carbohydrate chains and aglycones to block MDR in various types of tumor cells.

Thus, it was shown that a number of triterpene compounds isolated from marine organisms are able to block MDR in tumor cells and inhibit the growth of tumor cells that are resistant to antitumor agents. Continuation of research in this direction may lead to the creation of a new natural remedy based on holothurian triterpene glycosides that suppresses the activity of P-glycoprotein in tumor cells, and its further use as a medicinal drug for combined antitumor therapy together with known cytostatics.

\section{Materials and Methods}

\subsection{Drugs}

Monosulfated triterpene glycoside cucumarioside $\mathrm{A}_{2}-2\left(\mathrm{CA}_{2}-2\right)$ was isolated from the sea cucumber C. japonica using standard procedures [18]. The purity of glycoside was checked by the ${ }^{13} \mathrm{C} N \mathrm{NR}$. The chemical formula of $\mathrm{CA}_{2}-2$ is presented in Figure 1A. Water solution of $\mathrm{CA}_{2}-2$ was used in all experiments. Commercially available doxorubicin (DOX) was purchased from Pharmachemi BV (Netherlands) and dissolved in phosphate buffer saline (PBS).

\subsection{Animals and Cells}

CD-1 mice weighing 18-20 g were purchased from RAMS ‘Stolbovaya' nursery (Russia) and kept at the animal facility in standard conditions. All experiments were conducted in compliance with all of the rules and international recommendations of the European Convention for the Protection of Vertebrate Animals Used for Experimental Studies.

The museum tetraploid strain of mouse Ehrlich ascites carcinoma (EAC) was provided by the N.N. Blokhin Russian Oncology Center (Moscow, Russia). EAC cells were injected into the peritoneal cavity of CD-1 mice. Cells for experiments were collected 7 days after inoculation. For this purpose mice were killed by cervical dislocation, and the ascitic fluid containing tumor cells was collected with a syringe. The cells were washed two times by centrifugation at $2000 \mathrm{rpm}(450 \times g)$ for $10 \mathrm{~min}$ in PBS (pH 7.4) followed by resuspension in RPMI-1640 culture medium without serum. The cell number and viability were determined with a hemocytometer and the trypan blue staining procedure. The final cell concentration in the media was usually $2-5 \times 10^{6}$ cells $/ \mathrm{mL}$. 


\subsection{Calcein-AM Efflux Assay}

The experiments were initiated by washing the cells with PBS. Cells were treated with different concentration of $\mathrm{CA}_{2}-2$ at $37{ }^{\circ} \mathrm{C}$ for $30 \mathrm{~min}$. Then $0.25 \mu \mathrm{M}$ of calcein-AM (Molecular Probes, USA) was added to each well. After $15 \mathrm{~min}$ incubation at $37^{\circ} \mathrm{C}$, cells were washed twice with PBS and splitted to quantify P-gp activity by fluorescence in a microplate reader (Fluoroscan Accent, Finland) at $\lambda \mathrm{ex}=494 \mathrm{~nm}$ and $\lambda \mathrm{em}=517 \mathrm{~nm}$ [12]. Verapamil (Sigma, USA) was used as a positive control.

\subsection{MTT Viability Assay}

The cytotoxic activity of doxorubicin and the combined effect of doxorubicin and cucumarioside $\mathrm{A}_{2}$-2 were evaluated using the MTT method. For this purpose, $5 \times 10^{4}$ cells/well were seeded in 96-well microplates, then $20 \mu \mathrm{L}$ of DOX solution at different concentrations was added and microplates were incubated for $48 \mathrm{~h}$ in a $\mathrm{CO}_{2}$-incubator at $37^{\circ} \mathrm{C}$ and $5 \%$ of $\mathrm{CO}_{2}$. To study the combined effect, $20 \mu \mathrm{L}$ of cucumarioside $\mathrm{A}_{2}-2$ solution at different concentrations was added to wells first, and EAC cells were incubated during $2 \mathrm{~h}$ for blocking of MDR. Then $20 \mu \mathrm{L}$ of DOX ( $25 \mu \mathrm{M}$ final concentration) was added, and cells were incubated for $48 \mathrm{~h}$ at $37^{\circ} \mathrm{C}$ and $5 \%$ of $\mathrm{CO}_{2}$. Then the medium was replaced with $100 \mu \mathrm{L}$ of fresh medium containing $10 \mu \mathrm{L}$ of MTT solution (Sigma, USA) and microplates were incubated for another $4 \mathrm{~h}$. After that $100 \mu \mathrm{L}$ SDS-HCl solution was added and microplates were incubated again at $37^{\circ} \mathrm{C}$ for $4-18 \mathrm{~h}$. The optical density was measured with a microplate spectrophotometer Multiskan FC (Thermo Scientific, Canada) at $570 \mathrm{~nm}$. The cytotoxic activity of the substances was expressed as percent of cell viability in comparison with the control.

\subsection{Measurement of Doxorubicin Accumulation and Efflux}

The measurement of DOX accumulation in cells was performed according to the method in [19]. Cells were seeded on microscope imaging chambers at a concentration of $2 \times 10^{6}$ cells $/ \mathrm{mL}$. Then the chambers were placed on the microscope stage. To study the effect of glycoside on the time course of DOX accumulation, EAC cells were pre-exposed to different concentrations of $\mathrm{CA}_{2}-2$ for $30 \mathrm{~min}$ before being mounted in the microscope stage. DOX at a final concentration of $5 \mu \mathrm{M}$ were added to the cells and serial images at 1-min intervals were collected for $2 \mathrm{~h}$ and analyzed using a confocal microscope Axiovert 200M LSM510 META (Carl Zeiss, Germany). Doxorubicin fluorescence was excited with an argon laser at $488 \mathrm{~nm}$, and the emission was collected through a 505-nm long-pass filter. Post-data acquisition image analysis was performed using LSM 510 software release version 4.2 (Carl Zeiss, Germany). Cell images were analyzed as mean DOX fluorescent intensity per pixel in a region of interest (nuclei). Results were obtained from analyzing images from three to five experiments.

To study of doxorubicin efflux (retention), EAC cells were seeded to a 24-well plate. Different concentrations of $\mathrm{CA}_{2}-2$ were added to each well and plates were incubated at $37^{\circ} \mathrm{C}$ for $30 \mathrm{~min}$ to block MDR. Then, DOX ( $5 \mu \mathrm{M}$, final concentration) was added and plates were incubated for $2 \mathrm{~h}$ at $37^{\circ} \mathrm{C}$ to accumulate doxorubicin in the cells. After a certain time, aliquots of $100 \mu \mathrm{L}$ of the cell suspension were transferred into a $1.5 \mathrm{~mL}$ Eppendorf tube, pelleted by centrifugation, and washed twice with cold PBS. Then $100 \mu \mathrm{L}$ of cell suspension was replaced with a black 96-well microplate and the fluorescence of doxorubicin was measured using a Fluoroscan Accent (Finland) plate reader at $\lambda \mathrm{ex}=485 \mathrm{~nm}$ and $\lambda \mathrm{em}$ $=620 \mathrm{~nm}$.

\subsection{Study of Antitumor Activity of Doxorubicin in Vivo}

The influence of $\mathrm{CA}_{2}-2$ on the antitumor activity of DOX was assessed using the method in [20] with minor modifications. The tumors were maintained by intraperitoneal transplantation of $2 \times 10^{6}$ cells/mouse. Mice were treated with $\mathrm{CA}_{2}-2$ in a single dose of $10 \mu \mathrm{g} / \mathrm{kg}$ (intraperitoneal injection, i.p.) in a volume of $0.5 \mathrm{~mL}$ once a day for 5 days. The control group of mice received the same volume of saline. On the 7th day an equal amount of cancer cells from either $\mathrm{CA}_{2}-2$ pre-treated mice or from animals without pre-treatment were isolated and injected i.p. into fresh mice. Doxorubicin 
treatment ( $2 \mathrm{mg} / \mathrm{kg}$ i.p.) was started $24 \mathrm{~h}$ after tumor transplantation every other day only three times. Four groups of animals were formed with 5 mice in the group:

Group 1-control. The intact tumor cells were transplanted to animals. Then mice were treated with saline;

Group 2-control. The $\mathrm{CA}_{2}-2$ treated tumor cells were transplanted to animals. Then mice were treated with saline;

Group 3-experimental. The intact tumor cells were transplanted to animals. Then mice were treated with DOX;

Group 4 -experimental. The $\mathrm{CA}_{2}-2$ treated tumor cells were transplanted to animals. Then mice were treated with DOX.

Observation of the animals was continued for 70 days. The average life span (ALS) for mice bearing tumors was determined for all groups of animals.

\subsection{Statistics}

All data are expressed as mean \pm S.E. from three or more experiments, and they were statistically evaluated by Student's $t$-test. Differences were considered significant when $p<0.05$.

Author Contributions: Cell culture, animals, MDR analysis, writing, E.M.; confocal microscopy, T.G.; CA $2-2$ isolation and purification, A.S. and S.A.; conceptualization, methodology, writing, D.A.

Acknowledgments: This work was particularly supported by the Grant of FEB RAS No 19-MHT-017. The confocal microscopy investigation was done using equipment of the Instrumental Centre of Biotechnology and Gene Engineering of FSCEATB FEB RAS.

Conflicts of Interest: The authors declare no conflict of interest.

\section{References}

1. Endicott, J.; Ling, V. The biochemistry of P-glycoprotein mediated multidrug resistance. Annu. Rev. Biochem. 1989, 58, 137-171. [CrossRef] [PubMed]

2. Ford, J.M.; Halt, W.N. Pharmacology of drugs that alter multidrug resistance in cancer. Pharmacol. Res. 1990, 42, 155-199.

3. Menchinskaya, E.S.; Pislyagin, E.A.; Kovalchuk, S.N.; Davydova, V.N.; Silchenko, A.S.; Avilov, S.A.; Kalinin, V.I.; Aminin, D.L. Antitumor activity of Cucumarioside A 2-2. Chemotherapy 2013, 59, $181-191$. [CrossRef] [PubMed]

4. Reunov, A.A.; Reunov, A.V.; Pimenova, E.A.; Reunova, Y.A.; Menchinskaya, E.S.; Lapshina, L.A.; Aminin, D.L. Cucumarioside $\mathrm{A}_{2-2}$ stimulates apoptotic necrosis in Ehrlich ascites carcinoma cells. Dokl. Biol. Sci. 2015, 462, 161-163. [CrossRef] [PubMed]

5. Aminin, D.L.; Menchinskaya, E.S.; Pislyagin, E.A.; Silchenko, A.S.; Avilov, S.A.; Kalinin, V.I. Anticancer activity of sea cucumber triterpene glycosides. Mar. Drugs 2015, 13, 1202-1223. [CrossRef] [PubMed]

6. Dyshlovoy, S.A.; Menchinskaya, E.S.; Venz, S.; Rast, S.; Amann, K.; Hauschild, J.; Otte, K.; Kalinin, V.I.; Silchenko, A.S.; Avilov, S.A.; et al. The marine triterpene glycoside frondoside A exhibits activity in vitro and in vivo in prostate cancer. Int. J. Cancer 2016, 138, 2450-2465. [CrossRef] [PubMed]

7. Menchinskaya, E.S.; Aminin, D.L.; Silchenko, A.S.; Andriyashenko, P.V.; Avilov, S.A.; Kalinin, V.I.; Stonik, V.A. Agent Inhibiting Multiple Medicinal Stability of Tumor Cells. Patent RU 2494742 C1, 10 October 2013.

8. Menchinskaya, E.S.; Aminin, D.L.; Avilov, S.A.; Silchenko, A.S.; Andryjashchenko, P.V.; Kalinin, V.I.; Stonik, V.A. Inhibition of tumor cells multidrug resistance by cucumarioside $\mathrm{A}_{2-2}$, frondoside $\mathrm{A}$ and their complexes with cholesterol. Nat. Prod. Commun. 2013, 8, 1377-1380. [CrossRef] [PubMed]

9. Osman, A.M.; Bayoumi, H.M.; Al-Harthi, S.E.; Damanhouri, Z.A.; ElShal, M.F. Modulation of doxorubicin cytotoxicity by resveratrol in a human breast cancer cell line. Cancer Cell Int. 2012, 12, 47. [CrossRef] [PubMed]

10. Nielsen, D.; Maare, C.; Skovsgaard, T. Kinetics of daunorubicin transport in Ehrlich ascites tumor cells with different expression of P-glycoprotein: Influence of verapamil. Biochem. Pharmacol. 1994, 47, 2125-2135. [CrossRef] 
11. Nielsen, D.; Eriksen, J.; Maare, C.; Jakobsen, A.H.; Skovsgaard, T. P-glycoprotein expression in Ehrlich ascites tumour cells after in vitro and in vivo selection with daunorubicin. Br. J. Cancer 1998, 78, 1175-1180. [CrossRef] [PubMed]

12. Glavinas, H.; von Richter, O.; Vojnits, K.; Mehn, D.; Wilhelm, I.; Nagy, T.; Janossy, J.; Krizbai, I.; Couraud, P.; Krajcsi, P. Calcein assay: A high-throughput method to assess P-gp inhibition. Xenobiotica 2011, 41, 712-719. [CrossRef] [PubMed]

13. Jain, S.; Laphookhieo, S.; Shi, Z.; Fu, L.W.; Akiyama, S.; Chen, Z.S.; Youssef, D.T.; van Soest, R.W.; El Sayed, K.A. Reversal of P-glycoprotein mediated multidrug resistance by sipholane triterpenoids. J. Nat. Prod. 2007, 70, 928-931. [CrossRef] [PubMed]

14. Abraham, I.; Jain, S.; Wu, C.P.; Khanfar, M.A.; Kuang, Y.; Dai, C.L.; Shi, Z.; Chen, X.; Fu, L.; Ambudkar, S.V.; et al. Marine sponge-derived sipholane triterpenoids reverse P-glycoprotein (ABCB1)-mediated multidrug resistance in cancer cells. Biochem. Pharmacol. 2010, 80, 1497-1506. [CrossRef] [PubMed]

15. Aminin, D.L.; Chaykina, E.L.; Agafonova, I.G.; Avioiv, S.A. Antitumor activity of the immunomodulatory lead Cumaside. Int. Immunopharmacol. 2010, 10, 648-654. [CrossRef] [PubMed]

16. Kalinin, V.I.; Prokofieva, N.G.; Likhatskaya, G.N.; Schentsova, E.B.; Agafonova, I.G.; Avilov, S.A.; Drozdova, O.A.; Stonik, V.A. Hemolytic activity of triterpene glycosides from the holothurian order Dendrochirotida: some trends in the evolution of this group of toxins. Toxicon 1996, 34, 475-483. [CrossRef]

17. Agafonova, I.G.; Aminin, D.L.; Avilov, S.A.; Stonik, V.A. Influence of cucumariosides upon intracellular $\left[\mathrm{Ca}^{2+}\right] \mathrm{i}$ and lysosomal activity of macrophages. J. Agric. Food Chem. 2003, 51, 6982-6986. [CrossRef] [PubMed]

18. Avilov, S.A.; Stonik, V.A.; Kalinovskii, A.I. Structures of four new triterpene glycosides from the holothurian Cucumaria japonica. Chem. Nat. Compd. 1990, 26, 670-675. [CrossRef]

19. Shen, F.; Chu, S.; Bence, A.K.; Bailey, B.; Xue, X.; Erickson, P.A.; Montrose, M.H.; Beck, W.T.; Erickson, L.C. Quantitation of doxorubicin uptake, efflux, and modulation of multidrug resistance (MDR) in MDR human cancer cells. J. Pharmacol. Exp. Ther. 2008, 324, 95-102. [CrossRef] [PubMed]

20. Donenko, F.V.; Efferth, T.; Mattern, J.; Moroz, L.V.; Volm, M. Resistance to doxorubicin in tumor cells in vitro and in vivo after pre-treatment with verapamil. Chemotherapy 1991, 37, 57-61. [CrossRef] [PubMed] 